\title{
ANALISIS ATRAKSI INTERPERSONAL DAN SOSIAL LESBIAN
}

\section{ANALYSIS OF LESBIAN INTERPERSONAL AND SOCIAL ATTRACTIONS}

\author{
RP Febriana1a, M Dhani' ${ }^{1}$, R Ramadhany ${ }^{1}$ \\ ${ }^{1}$ Universitas Djuanda, Bogor, Jawa Barat, Indonesia \\ a Korespondensi: Ratih Putri Febriana, Email: ratihputrifebriana@gmail.com \\ (Diterima: 02-07-2018; Ditelaah: 02-07-2018; Disetujui: 16-10-2018)
}

\begin{abstract}
Lesbian in Sukabumi City can't be handled thoroughly, according to the statment from department of social there were about 200 LGBT including lesbian in it. The aims of this study is to know how factors of interpersonal attraction thing to lesbian in Sukabumi City. This study was used qualitative method, the data were collected by in-depth interview, participatory observation and literature studies. The study found if seven from nine factors of interpersonal attraction influence the lesbian in Sukabumi City, that is: similarity of interpersonal characteristics, emotional distress,physical attractiveness, reward, familiarity, closeness, and competence. Department of social program with "person to person outreach"considered not be able to be an effective solution for handled the lesbian. According to the data from five informan, researcher made some engineering model for handled lesbian, as effort for help the government in handle the lesbian.
\end{abstract}

Key words: interpersonal attraction, lesbian, handling of lesbian.

\begin{abstract}
ABSTRAK
Lesbian di Kota Sukabumi belum dapat ditangani secara tuntas, menurut dinas sosial sedikitnya ada 200 LGBT yang tercatat termasuk lesbian didalamnya. Penelitian ini bertujuan untuk mengetahui bagaimana faktor dalam atraksi interpersonal terjadi pada seorang lesbian di Kota Sukabumi. Penelitian ini menggunakan metode kualitatif, pengumpulan data dilakukan melalui teknik wawancara Indepth Interview, observasi partisipati dan studi kepustakaan. Hasil penelitian menunjukan bahwa tujuh dari sembilan faktor atraksi interpersonal berpengaruh kuat terhadap lesbian di Kota Sukabumi, yaitu : kesamaan karakterisik personal, tekanan emosional, daya tarik fisik, ganjaran, familiarity, kedekatan, dan kemampuan . Program dinas sosial dengan "penjangkauan person to person" dinilai belum mampu menjadi solusi efektif dalam menangani lesbian. Berdasarkan data yang didapatkan dari kelima informan, peneliti membuat rekayasa model penanganan lesbian, sebagai upaya untuk membantu pemerintah menangani lesbian.
\end{abstract}

Kata kunci: atraksi interpersonal, lesbian, penanganan lesbian.

Febriana, R. P., Dhani, M., \& Ramadhany, R. (2018). Analisis Atraksi Interpersonal dan Sosial Lesbian. Jurnal Sosial Humaniora 9(2): 106-116.

\section{PENDAHULUAN}

Suatu ketertarikan tidak terbentuk dengan sendirinya, melainkan melalui suatu proses yang dapat dijelaskan. Jika proses terbentuknya ketertarikan tersebut benar dapat diketahui, maka merekayasa suatu ketertarikan interpersonal sebenarnya dapat menjadi mungkin (Rahman, 2013: 161). 
Atraksi interpersonal adalah perilaku kita terhadap bagaimana diri kita menyukai orang lain, sikap positif dan daya tarik seseorang. Makin tertarik kita dengan orang lain maka semakin besar kecenderungan kita untuk berkomunikasi dengan orang lain (Rahmat, 1985: 110).

LGBT yang merupakan abreviasi dari lesbian, gay, biseksual, dan trangender bukan hal tabu ditelinga manusia. Terlebih pada seorang Muslim, kaum LGBT sudah ada pada zaman nabi Luth As. Dikisahkan bahwa kaum Sodom mendapat azab dengan dibenamkan ke dalam perut bumi akibat perilaku menyimpang dimana laki-laki berzina dengan sesama jenis.

Homoseksual adalah kesenangan yang terus menerus terjadi dengan pengalaman seksualitas diri yang melibatkan sesama jenis, yang dapat atau mungkin saja tidak dapat dilakukan dengan orang lain. Dengan kata lain, homoseksual membuat perencanaan yang disengaja untuk memuaskan diri dan terlibat dalam fantasi atau perilaku seksual dengan sesama jenis (Olson, 2000: 10).

Pada hakikatnya pasangan lesbian meminta pengakuan dan perlakuan sama dari masyarakat. Namun, Indonesia adalah negara ketuhanan yang berlandaskan pancasila. Sila pertama "Ketuhanan Yang Maha Esa" menjadi tolok ukur utama lesbian tidak diterima di Indonesia. Karena tidak ada satu agamapun yang membenarkan perilaku lesbian.

Dalam Undang-Undang (UU) Republik Indonesia nomor 1 tahun 1974 tentang Perkawinan pasal 1 yang berbunyi "Perkawinan ialah ikatan lahir batin antara seorang pria dengan seorang wanita sebagai suami isteri dengan tujuan membentuk keluarga (rumah tangga) yang bahagia dan kekal berdasarkan ketuhanan yang maha esa." Dalam Undang undang tersebut dapat disimpulkan dengan jelas bahwa perkawinan dapat dikatakan sah apabila antara seorang pria dan wanita, bukan antara gender yang sama.
Peran pemerintah dalam menangani lesbian dianggap masih kurang. Lesbian tidak bisa diberantas secara paksa, harus ada pendekatan, kajian-kajian lembut yang menyentuh hati sehingga seorang lesbian dapat sadar dengan sendirinya tanpa paksaan. Jika dengan paksaan, mereka akan memberontak dan semakin menjadi-jadi.

Sebagian lesbian menunjukan dirinya kepada masyarakat karena mereka beranggapan "selagi tidak membebani orang lain dan lingkungannya maka tidak apaapa", sebagian besar lainnya menutup diri karena mereka malu dengan sadar melawan norma-norma yang berlaku.

Ketertarikan terhadap individu lain merupakan hal yang wajar bila terjadi antara seorang perempuan kepada laki-laki, namun bagaimana bila atraksi interpersonal terjadi pada seorang perempuan kepada perempuan lainnya. Kasus lesbian merupakan kontroversi yang terjadi di dalam budaya Indonesia. Namun, walaupun mereka mengetahui bahwa ini merupakan hubungan yang tidak sesuai dengan norma yang berlaku, ternyata faktor atraksi interpersonal mempengaruhi dan mendorong hal tersebut (Khairina, 2013). Setiap lesbian bisa kembali pulih hanya saja proses yang dilakukan akan berlangsung cukup lama. Seseorang harus meninggalkan kebiasaannya dan menjadi sesuatu yang baru atau meninggalkan dunia yang lama menuju ke dunia yang baru adalah sesuatu yang sangat sulit (Fatimah, 2012: 123).

Berdasarkan latar belakang diatas maka penulis beranggapan perlunya perhatian lebih terhadap analisis atraksi interpersonal yang terjadi dalam diri seorang lesbian khususnya di Kota Sukabumi.

\section{MATERI DAN METODE}

Metode yang digunakan dalam penelitian ini adalah kualitatif. Penelitian kualitatif merupakan penelitian yang terjadi secara alamiah, apa adanya, dalam situasi normal yang tidak dimanipulasi keadaan dan kondisinya, menekan pada deskripsi secara 
alami (Arikunto, 2006). Penelitian kualitatif merupakan proses penelitian yang berkesinambungan sehingga tahap pengumpulan data dan analisis dilakukan bersamaan selama proses penelitian (Suyanto dan Sutinah:172).

Lokasi penelitian bertempat di lingkungan Kota Sukabumi, yaitu di kediaman informan dan tempat makan. Informan dibagi kedalam 2 jenis terdiri dari: (1) Lesbian Kota Sukabumi dengan latar belakang yang berbeda, (2) Dinas Sosial Kota Sukabumi dan MUI Kota Sukabumi.

Penentuan sampel menggunakan teknik snowball sampling ( Sample bola salju), merupakan teknik penentuan sample yang awalnya berjumlah kecil, kemudian sampel berikutnya ini menjadi berkembang semakin banyak dan seterusnya ibarat bola salju yang menggelinding ke bawah semakin besar bentuknya (Ruslan, 2004: 157). Penentuan informan dimulai dari satu partisipan, lalu informan tersebut diminta pendapatnya untuk melibatkan partisipan lain yang bersedia menjadi informan.

Peneliti mendapatkan data dari 5 informan yang nama dan identitasnya tidak dapat disebutkan atas permintaan informan. Nama samaran informan dalam penelitian ini adalah Biru, Hijau, Ungu, Jingga, dan Abu. Mereka berprofesi sebagai pelajar, mahasiswa, karyawan swasta, dan freelance dengan usia 17 hingga 24 tahun. Diantara mereka ada yang berperan sebagai laki-laki (butchi) dan ada yang berperan sebagai perempuan (femme). Masing-masing informan saling mengenal tetapi tidak ada yang menjadi pasangan.

Dalam pengumpulan data peneliti melakukan wawancara mendalam (in-depth interview) dan observasi secara tidak terstruktur yang harus dilakukan kapan saja, dan dapat dilakukan pada waktu dan tempat tertentu sesuai kesepakatan mengikuti permintaan informan, mengingat informasi yang diberikan bersifat pribadi yang jarang keluarga dari informanpun mengetahui.
Dalam hal ini secara berkala peneliti datang ke lokasi penelitian, bersosialisasi dan berpartisipasi dalam kehidupan sosial informan. Menurut Rahmat (2015: 247) peneliti tidak akan menemukan informasi yang falid jika tidak tercipta hubungan saling mempercayai. Hubungan tidak harus mendalam, yang terpenting adalah terjadinya arus bebas dan keterusterangan dalam komunikasi informasi yang berlangsung dengan informan penelitian, tanpa kecurigaan dan upaya untuk saling menutup diri.

Dalam hal ini peneliti menjadikan data atau informasi yang telah dikumpulkan disajikan dalam bentuk uraian dan sekaligus memberikan makna atau interprestasi sehingga informasi tersebut memiliki signifikan ilmiah atau teoritis. Teknik analisa data ini menguraikan, menafsirkan dan menggambarkan data yang terkumpul secara sistemik dan sistematik. Untuk menyajikan data tersebut agar lebih bermakna dan mudah dipahami adalah menggunakan interactive model analysis dari Miles dan Huberman (1992:16). Dalam model ini proses analisis dibagi menjadi tiga tahap yaitu pengumpulan data, reduksi data, penyajian data, dan verifikasi data atau penarikan simpulan. Reduksi data yang dilakukan antara lain dengan memfokuskan pada hal-hal yang penting dan membuang data yang tidak diperlukan kemudian menyusun data sesuai dengan formatnya. Hasil wawancara disusun kata demi kata menjadi bentuk verbatim.

\section{HASIL DAN PEMBAHASAN}

Tidak ada perempuan yang berniat untuk menjadi seorang lesbian. Biasanya terjadi secara tidak sengaja, berawal dari sebuah pertemanan dan kedekatan menjadikan timbul rasa nyaman sampai berkomitmen memadu kasih dan menjadikan mereka sulit keluar dari kehidupan lesbian yang merupakan sebuah zona yang dianggap nyaman. 
Saat pertama kali menjadi seorang lesbian, seseorang tersebut akan berusaha mencari teman sesama lesbian untuk menemukan pengakuan dari kelompok. Dimulai dari mencari teman di jejaring sosial, lalu berteman di aplikasi chatting, sehingga berkenalan dan saling bertukar informasi. Jarak tidak menjadi penghalang untuk membuat mereka saling mengenal atau saling mengetahui. Data yang ada menyebutkan bahwa mencari teman sesama lesbian atau mencari pasangan bukan hal yang sulit. Pada masa di mana Blackberry Messenger menjadi aplikasi chat nomer $1 \mathrm{di}$ Indonesia, lesbian seperti mempunyai jaringan khusus untuk saling berkenalan dan bertukar informasi. Mereka dapat memiliki 2 akun BBM, satu akun digunakan untuk berkomunikasi dengan teman normal dan satu akun untuk berkomunikasi khusus dengan lesbian. Pada akun khusus, mereka bebas mengekspresikan diri dan tidak menutupi orientasi seksualnya agar dapat dengan mudah berkenalan dengan sesama lesbian. Bukan hanya akun BBM saja, tetapi juga akun sosial media lain.

Dalam menjalani kehidupanya, lesbian di Kota Sukabumi seperti membentuk kelompok masing-masing secara tidak langsung, kelompok dalam hal ini merupakan rekan bergaul yang di dalamnya juga terdapat heteroseksual namun didominasi oleh lesbian, dalam kelompok tersebut terjadi saling keterbukaan, memahami dan kepercayaan, mereka saling melindungi orientasi seksual sesama rekannya dari hadapan orang tua dan masyarakat agar citra yang tergambar adalah "perempuan normal". Sikap yang dimiliki oleh individu dalam kelompok cenderung sama dengan rekan sekelompoknya. Kelompok satu dengan kelompok lain biasanya saling mengetahui, meskipun tidak saling mengenal satu sama lain. Apabila salah satu anggota kelompok mengenal aggota kelompok lain, kemungkinan dua kelompok tersebut dapat berkumpul sehingga menjadi kelompok yang lebih besar.

\section{Model Atraksi Interpersonal}

Menjadi seorang yang mengalami penyimpangan orientasi seksual tidak memandang tingkat pendidikan, status sosial, keadaan ekonomi, atau latar belakang lainnya. Berangkat dari latar belakang manapun dan apapun, tidak dapat menutup kemungkinan seorang menjadi lesbian jika tidak berpendirian kuat terhadap keyakinan dan norma yang berlaku. Seseorang yang sudah menikahpun, selain memiliki suami juga dapat memiliki pasangan lesbiannya sendiri. Terkadang begitu orang tua mengetahui mengenai orientasi seksual anaknya, langsung menjodohkan. Pernikahan secara paksa tidak bisa begitu saja merubah orientasi seksual seseorang, sehingga individu tersebut masih menjalani kehidupan lesbian dibelakang suami dan sanak saudara.

Menurut data yang diperoleh dari kelima informan, terdapat faktor-faktor atraksi interpersonal dalam menjalani hubungan lesbian. Bermula dari perkenalan dan ditemukannya kesamaan karakteristik personal. Komunikasi diantara kedua belah pihak menjadi efektif dimana mereka saling merasa nyaman sehingga muncul perasaan cinta sampai menjalin hubungan yang lebih intim sebagai pasangan lesbian.

Informan mendeskripsikan bahwa mereka mengetahui aturan mengenai perilakunya yang menyimpang. Setiap informan menyadari bahwa perilaku lesbian bukan hal yang patut dipertahankan sampai tua. Mereka juga ingin kembali ke jalan lurus yang tidak melanggar aturan agama dan negara, berkeluarga dan hidup bahagia dengan jodoh yang digariskan oleh Tuhan. Namun, keinginan saja tidak cukup untuk membawa mereka kembali ke jalan yang seharusnya. Dibutuhkan peran pihak lain untuk membawanya keluar dari zona nyaman.

Temuan dalam penelitian ini menunjukan bahwa ada pengaruh kuat dan lemah dari aspek yang terdapat pada faktor Atraksi interpersonal dengan data yang diperoleh dari informan. 
Dari hasil wawancara diperoleh bahwa dalam faktor personal, kesamaan karakteristik merupakan aspek utama yang kuat. Dimana ketertarikan muncul ketika mereka memiliki kegiatan dan kesukaan yang sama. Bila kedua belah pihak sering bertemu dalam suatu kegiatan yang sama maka mereka tidak akan merasa asing meskipun belum mengenal. Sebuah persamaan karakteristik pribadi juga dapat dijadikan bahan untuk memulai sebuah perbincangan.

Selain kesamaan karakteristik, tekanan emosional juga berpengaruh kuat dalam memulai sebuah hubungan lesbian. Dalam kondisi lemah atau berada dalam tekanan, informan cenderung lebih membuka diri dan menerima orang baru karena merasa membutuhkan sandaran dan kepedulian lebih. Informan merasa membutuhkan seseorang yang bersimpati dan dapat merangkulnya, untuk bisa bangkit dari segala tekanan yang sedang dialami. Namun, ada informan yang kesulitan menerima orang baru karena terlalu fokus memikirkan masalah yang sedang dihadapi sehingga cenderung menyelesaikan permasalannya terlebih dahulu setelah itu baru dapat menerima orang baru.

Naik turunnya masalah percintaan informan menimbulkan kegelisahan di hati dan pikirannya. Namun, mereka tetap percaya diri dan tidak memandang lemah pada dirinya. Informan beranggapan bila putus cinta adalah hal yang wajar, bukan karena suatu kesalahan akibat kekurangan yang ada dalam dirinya. Sehingga, harga diri yang rendah tidak menjadi alasan yang kuat untuk menjadi seorang lesbian, namun ada seorang informan yang terkadang tidak percaya diri dalam menyukai seseorang karena memandang lemah pada diri. Dapat dikatakan bahwa harga diri yang rendah memiliki pengaruh yang lemah dalam hubungan lesbian.

Isolasi sosial merupaka aspek yang lemah dalam mempengaruhi atraksi interpersonal lesbian di Kota Sukabumi. Dari hasil wawancara dengan kelima informan, mereka mendeskripkan awal mula mereka menjadi lesbian bukan karena trauma disakiti oleh seorang laki-laki. Mereka berteman dengan siapapun, dari berbagai latar belakang dan tidak membatasi diri untuk berteman dengan laki-laki. Kehidupan mereka tidak terisolasi dari lakilaki maupun perempuan.

Selain faktor personal, atraksi interpersonal juga dipengaruhi oleh faktor situasional. Kelima aspek dalam faktor situasional berperan kuat dalam atraksi interpersonal. Bermula dari daya tarik fisik, sesuai dengan label yang lesbian gunakan, mereka dapat menyukai perempuan yang berpenampilan menarik perhatiannya. Seorang lesbian berlabel butchie akan menaruh perhatian lebih pada perempuan dengan rambut panjang, wajah manis dan berpenampilan feminim. Begitupun sebaliknya, seorang lesbian berlabel femme akan menaruh perhatian lebih pada perempuan dengan rambut pendek, berkegiatan seperti laki-laki dan berpenampilan maskulin. Jika mereka saling mengetahui mengenai orientasi seksual masing-masing maka dapat menjadi jalan untuk berkenalan hingga memulai hubungan. Selain perempuan berlabel butchie yang berpasangan dengan femme, juga tidak menutup kemungkinan apabila perempuan feminim menyukai perempuan feminim dan perempuan yang berpenampilan tomboy menyukai perempuan tomboy. Dalam istilah lesbian hal ini dinamakan dengan $\mathrm{F} 2 \mathrm{~F}$ (femme to femme) atau B2B (butchie to butchie).

Setelah kedua belah pihak mengetahui keberadaan masing-masing maka mereka bukan orang asing lagi, meskipun hanya sekedar sering melihat atau sering berpapasan tanpa saling mengenal. Dari familiarity tersebut mereka dapat berkenalan dan menjalin hubungan pertemanan sehingga timbul komunikasi efektif yang membuat kedua belah pihak semakin mengalami kedekatan dan terjadinya hubungan yang lebih intim sampai menjadi pasangan lesbian. Seseorang sudah dikenal, bersikap positif sesuai harapan dan akrab biasanya lebih 
disukai dari pada orang yang masih asing bagi individu. Jarang bila seseorang tiba-tiba menyukai orang yang baru saja bertemu, meskipun ada istilah yang dinamkan dengan "cinta pada pandangan pertama".

Dalam sebuah kedekatan diantara kedua belah pihak terjalin sebuah kenyamanan di mana mereka saling memenuhi kebutuhan akan perasaan masing masing. Kedua belah pihak cenderung saling memberikan ganjaran atas hal yang dilakukan oleh pasangannya. Seperti pasangan hetero seksual, mereka akan merasa lebih nyaman ketika apa yang mereka lakukan dihargai dengan berbagai tanggapan dan pujian, diberi dorongan moral dan berbagai hal yang dapat meningkatkan harga diri. Ganjaran yang diterima bisa berupa ucapan maupun perlakuan.

Selain daya tarik fisik, ganjaran, kedekatan dan familiarity, kemampuan seseorang juga memberikan pengaruh kuat untuk disukai dan menyukai seseorang. Terlebih jika kemampuan yang dimiliki sama dengan informan dan juga dikembangkan, maka informan akan beranggapan "bila menjalin hubungan dengannya, akan mengerti kegiatan satu sama lain dan dapat saling memahami". Informan menyebutkan bahwa mereka merasa dapat kagum pada seseorang yang memiliki kemampuan khusus.Namun, dua orang informan tidak begitu mempedulikan kemampuan seseorang karena berpendapat bahwa nilai utama dalam menyukai seorang perempuan adalah sebuah kenyamanan.

Menurut data yang diperoleh, dari sembilan aspek dalam faktor yang mempengaruhi terjadinya Atraksi Interpersonal, lesbian di Kota Sukabumi hanya mengalami 8 aspek dan ada 7 aspek yang mempengaruhi dengan kuat yaitu : kesamaan karakterisik personal, tekanan emosional, daya tarik fisik, ganjaran, familiarity, kedekatan, dan kemampuan. Harga diri yang rendah dan Isolasi sosial tidak berpengaruh kuat dalam atraksi interpersonal lesbian.

Dalam atraksi interpersonal (liking theory) ada Reinforcement theory. Teori ini menjelaskan bahwa seseorang menyukai dan tidak menyukai orang lain adalah sebagai hasil belajar (learning). Dalam hal ini ada tiga unsur learning, yaitu asosiatif, instrumental, dan sosial. Informan menyebut hal ini sebagai "PDKT", pada tahap ini informan mempelajari hal-hal mengenai calon pasangannya sampai pada hubungan yang lebih intim. Dari mulai sebatas melihat di media sosial, mengamati unggahan, komunikasi ringan sampai rutin, hingga pertemuan-pertemuan. Jika sesuai harapan maka tahap dilanjutkan pada tinggat yang lebih dekat sampai membuat komitmen bersama.

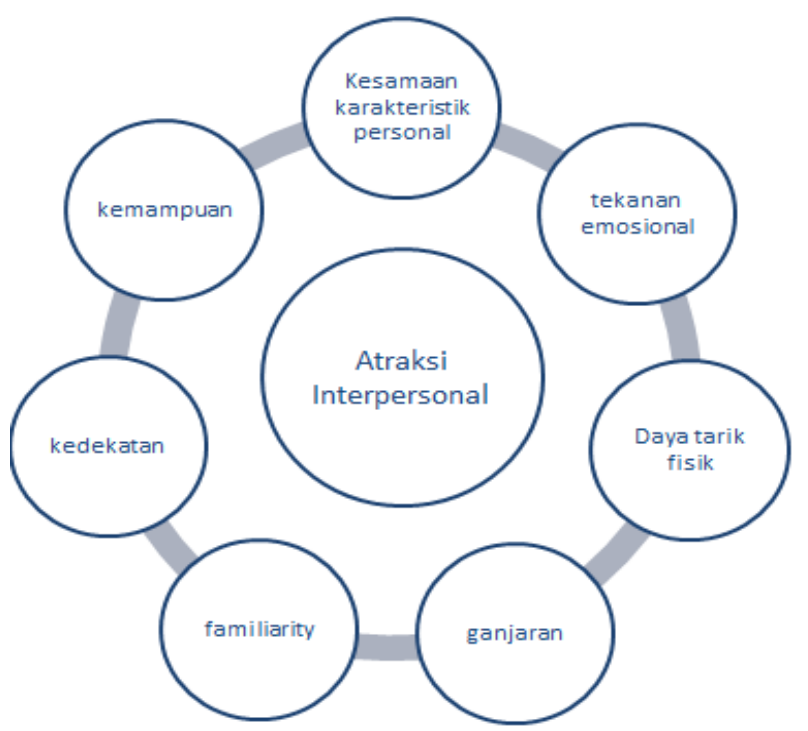

Gambar 1 Faktor atraksi interpersonal

Pada unsur belajar asosiatif, sikap menyenangi dan tidak menyenangi seseorang berdasarkan pengalaman yang diasosiasikan pengalaman. Informan menyukai seorang perempuan yang mempunyai pengalaman menyenangkan bersama, jika ada pengalaman yang kurang menyenangkan maka ketertarikan bisa selesai begitu saja atau dapat dipertimbangkan untuk diberi kesempatan kedua. Informan menyebutkan bahwa aktivitas yang mereka lalui bersama di tempat bekerja, sekolah, atau lingkungan bermain cenderung menyenangkan sehingga ada suatu ingatan positif megenai seseorang.

Pada unsur belajar instrumental, seorang individu dapat menyukai individu lain yang memberikan imbalan (reward) dan tidak 
menyukai seseorang yang memberikan hukuman kepada dirinya. Informan merasa akan lebih nyaman ketika apa yang mereka lakukan dihargai dengan berbagai tanggapan dan pujian, diberi dorongan moral dan berbagai hal yang dapat meningkatkan harga diri. Ganjaran yang diterima bisa berupa ucapan maupun perlakuan. Saat berulang tahun informan diberi suatu hadiah oleh seorang perempuan, diberikan ucapan selamat saat mendapatkan sebuah pencapaian, juga direspon positif saat sedang bercerita, begitupun sebaliknya.

Dalam unsur belajar sosial, seseorang individu cenderung lebih menyukai individu yang disukai oleh orang lain atau oleh lingkungan sosial dan sebaliknya. Saat mulai menyukai dan mendekati seorang perempuan, informan akan mencari tahu mengenai perempuan tersebut dari kerabat yang bersangkutan. Bertanya mengenai karakteristik hingga pandangan kerabat yang bersangkutan mengenai perempuan yang dimaksud. Jika jawabannya negatif, maka informan akan mengamati dan menilai apakah cocok dengan dirinya atau tidak. Jika jawabannya positif, maka informan akan semakin yakin.

Atraksi interpersonal hanya membahas mengenai perilaku terhadap bagaimana seorang individu menyukai individu lain, sikap positif dan daya tarik seseorang. Terlepas dari pada itu, dengan siapa seorang individu dapat menyukai dan disukai diluar dari pembahasan teori ini.

\section{Rekayasa Model Pembinaan Lesbian}

Dalam PMKS (Penyandang Masalah Kesejahteraan Sosial) di Kota Sukabumi LGBT dikategorikan sebagai kelompok minoritas. Kelompok minoritas adalah individu atau kelompok yang tidak dominan dengan ciri khas bangsa, suku bangsa, agama atau bahasa tertentu yang berbeda dari mayoritas penduduk dan berperilaku menyimpang. Sampai pada tahun 2018, menurut Dinas Sosial setempat di Kota Sukabumi ada sekitar 200 orang LGBT termasuk lesbian di dalamnya. Seperti gunung es, jumlahnya tidak diketahui secara pasti karena mereka cenderung menutup diri terlebih dari keluarganya.

Pemerintah Kota Sukabumi tidak tinggal diam dalam menangani LGBT, sehingga membentuk tim terpadu dengan melibatkan diantaranya adalah dinas sosial, Komisi Penggulangan AIDS (KPA), dan MUI. Lembaga tersebut saling berkoordinasi dan menangani LGBT sesuai dengan perannya masing-masing.

Menurut Dinas Sosial perilaku LGBT merupakan sebuah penyimpangan yang dapat menimbulkan permasalahan sosial sampai pada keretakan rumah tangga bila terjadi pada pasangan yang sudah berumah tangga. Dalam hal ini dinas sosial berperan untuk mendorong dan menyadarkan kaum LGBT. Penyimpangan mengacu pada perilaku, cara-cara bertindak, sikap, keyakinan dan gaya yang melanggar normanorma, aturan, etika dan harapan masyarakat (Scott, 2011: 9).

Dinas sosial sendiri memiliki nara hubung dari komunitas LGBT agar dapat mengkoordinasi anggota dari komunitas tersebut untuk berkumpul sehingga dinas sosial dapat melaksanakan program penjangkauan rehabilitasi sosial (resos), hal ini dilakukan dengan pendekatan person to person untuk melihat faktor resiko, apa yang dapat menyebabkan seseorang dapat menyukai sesama jenis dan bertanya langsung "ingin diperlakukan seperti apa agar terlepas dari kehidupan LGBT". Karena dalam hati kecil mereka terdapat keinginan untuk berubah, namun tidak diikuti dengan tindakan nyata. Mereka bercita-cita untuk mempunyai keturunan dan juga menyadari bila menjalin hubungan dengan sesama jenis tidak akan mendapatkan keturunan.

Pemerintah telah menyediakan panti rehabilitasi sosial bagi yang mengingikannya. Bila seseorang tersebut tidak menginginkan untuk dikirim ke panti rehabilitasi sosial maka akan terjadi penolakan dan dapat menghambat proses rehabilitasi. Selain itu, pengiriman LGBT ke panti bukan hal yang mudah. Mengingat 
cukup panjangnya waktu yang dibutuhkan untuk rehabitasi dan kesulitan mereka mendapatkan izin dari keluarga, karena merekapun rata-rata menyembunyikan orientasi seksual mereka dari keluarga.

Selain program pendekatan rehabilitasi sosial, juga terdapat program Kampanye Sosial. Dinas sosial melakukan penyuluhan kepada masyarakat di 33 kelurahan agar berhati-hati mengenai LGBT, penyuluhan ini juga bersamaan dengan penyuluhan perda tentang kesejahteraan sosial.

Menurut MUI perilaku LGBT jelas merupakan penyimpangan dari kaidah agama sehingga harus diluruskan sesuai syariah Islam. MUI memiliki 2 fungsi, yang pertama sebagai lembaga fatwa sesuai dengan syariah Islam dan yang kedua berfungsi sebagai khodimul Ummah (pembina dan pengayom umat). Untuk menangani LGBT, MUI menjalankan fungsinya yang kedua. Dalam hal ini, MUI melakukan tindakan preventif melalui dakwah, khutbah dan seminar. MUI Kota Sukabumi telah beberapa kali menyelenggarakan seminar yang diikuti oleh para pengurus MUI tingkat kota, kecamatan, dan kelurahan.

Dalam fitrahnya, manusia telah diciptakan berpasang-pasangan. Seorang perempuan diciptakan dari tulang rusuk laki-laki, tulang rusuk satu dan yang lain tidak akan tertukar karena sudah ditakdirkan berpasangan. Berpasangpasangan maksudnya adalah yang berlainan jenis, lain jasmani, lain rohani, lain pemikiran, lain perasaan, disatukan akan agar menjadi sebuah keluarga yang bahagia. Meskipun dalam pengertian manusia ada yang mengatakan LGBT juga dapat bahagia, namun sesungguhnya dalam kajian agama, kebahagiaan tersebut merupakan kebahagiaan yang semu. Bagaimana bisa dikatakan bahagia bila sama sekali tidak mendapat kemungkinan untuk mempunyai keturunan. Rantai keturunan keluarga akan berhenti pada pasangan LGBT. Bilamana LGBT dibiarkan, maka bisa sampai mengancam populasi manusia di bumi, karena rantai keluarga yang terputus dan penularan penyakit mematikan (AIDS).

Fenomena gunung es sangat cocok dalam menggambarkan jumlah lesbian di Kota Sukabumi. Dari sekitar 200 orang LGBT yang tercatat dan dibina melalui program penjangkauan person to person oleh dinas sosial, kelima informan belum mengalami penjangkauan tersebut bahkan tidak mengetahuinya.

Pada berita yang dimuat oleh Kompas.com, dalam RKUHP peraturan tentang LGBT masuk dalam aturan mengenai perbuatan cabul sesama jenis yang diatur dalam pasal 495, pasal itu berbunyi:

1. Setiap orang yang melakukan perbuatan cabul dengan orang yang sama jenis kelamin:

a. Di depan Umum, dipidana dengan pidana penjara paling lama 1 (tahun) 6 (enam) bulan atau pidana denda paling banyak kategori II.

b. Secara paksa, dengan kekerasan atau ancaman kekerasan, dipidana dengan pidana penjara paling lama 9 (sembilan) atau pidana denda paling banyak kategori III.

c. Yang dipublikasikan sebagai muatan pornografi, dipidana dengan pidana penjara paling lama 9 (sembilan) atau pidana denda paling banyak kategori III.

2. Setiap orang yang melakukan perbutan cabul dengan orang yang sama jenis kelamin, yang diketahui atau patut diduga belum berumur 18 (delapan belas) tahun, dipidana dengan pidana penjara paling lama 12 (dua belas) tahun atau pidana denda paling banyak kategori IV.

3. Dalam perbuatan sebagaimana dimaksud ayat (2) dilakukan dengan kekerasan atau ancaman kekerasan dipidana dan pidana paling lama 15 (lima belas) tahun pidana denda paling banyak kategori $\mathrm{V}$. 
Persoalannya adalah ketika pelaku LGBT melakukan beberapa hal yang dilarang dalam ketentuan diatas dan diberikan hukuman, bagaimana pelaku LGBT yang melakukan nya tidak didepan umum, tidak secara paksa, tidak dengan kekerasan, tidak dengan ancaman kekerasan dan tidak dipublikasikan karena itulah sangat perlu dilakukan perluasan lingkup perbuatan zina. (Famela: 2018)

Program yang disiapkan pemerintah untuk menangani lesbian atau LGBT dinilai belum mampu menjadi solusi yang tepat untuk menangani lesbian. Berdasarkan data yang didapatkan dari kelima informan maka peneliti membuat rekayasa model penanganan lesbian yang dapat dilakukan pemerintah bersama dengan lembaga swadaya masyarakat yang konsen dalam penanganan LGBT, yaitu :

\section{Tindakan Preventif}

Dalam hal ini, peneliti membagi model penanganan berdasarkan tingkat pendidikan. Karena, disesuaikan dengan daya tangkap individu tersebut.

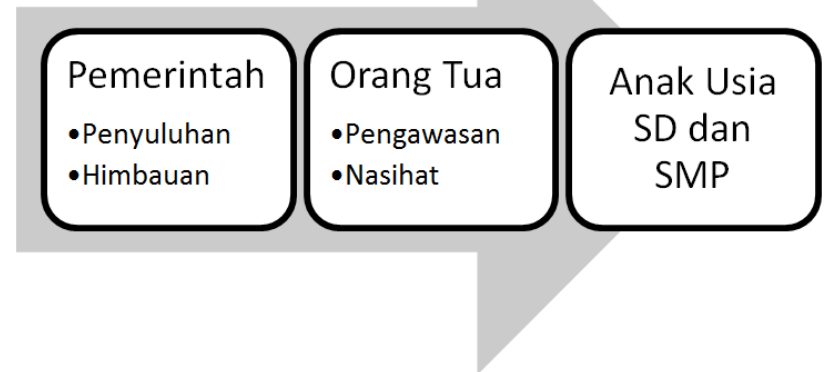

Gambar 2 Tindakan preventif

Penyuluhan kepada masyarakat; agar orang dewasa khusunya orang tua memberikan perhatian lebih kepada anak usia sekolah dasar agar terhindar dari penyimpangan seksual dan mengenali rekan bermain anak. Karena empat dari lima informan menyebutkan bahwa sudah mulai tertarik pada sesama jenis sejak sekolah dasar.

Menginjak masa sekolah menengah, merupakan masa peralihan dari anak-anak menjadi dewasa sehingga perhatian orang tua dan guru sangat diperlukan.

Penyuluhan di Sekolah Menengah Atas/sederajat dan kajian-kajian ke agamaan; mengenai bahaya dari perilaku lesbian pada masa sekolah menengah atas daya pikir dan olah data sudah cukup matang sehingga dapat dilakukan kajian serta seminar langsung pada individu tersebut.

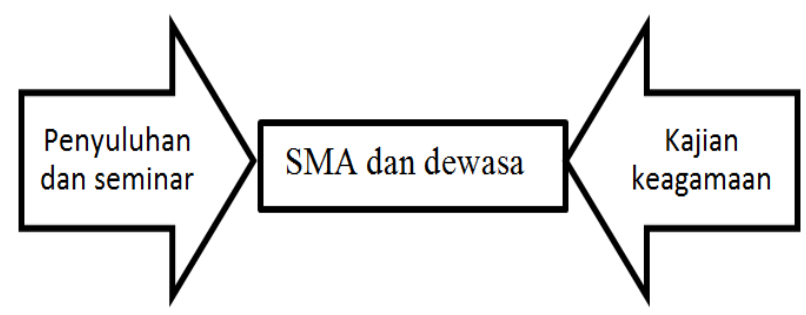

Gambar 3 Tindakan preventif

\section{Tindakan Represif}

Menurut data yang didapatkan, informan mulai berani menjalin hubungan dengan sesama jenis dimulai dari Sekolah Menengah Pertama. Pada masa ini, orang tua sudah membekali anak-anak dengan gadget, bahkan dari mulai sekolah dasarpun ada yang sudah dibekali. Dengan mudahnya anak usia SMP bermain sosial media, terlebih orang dewasa, maka dari itu peneliti menilai iklan di media sosial efektif untuk membantu menyadarkan dalam menangani lesbian. Misalkan, muncul di feed atau story Instagram atau dapat juga memanfaatkan jasa endorse kepada akun berfollowers tinggi atau yang biasa disebut dengan "Selebgram".

Selain program person to person yang dilakukan oleh dinas sosial saat berkumpul dengan para LGBT, juga dapat dilakukan kegiatan keagamaan seperti mengaji atau kultum. Mengingat sulitnya pengiriman lesbian ke panti rehabiliasi, peneli menilai seorang lawan jenis (untuk LGBT) atau lakilaki juga efektif untuk menangani lesbian, jika memiliki rekan yang mengalami penyimpangan orientasi seksual dan berniat menyadarkan, alangkah lebih baiknya dibantu disadarkan oleh lawan jenis. Jika dilakukan oleh sesama jenis dikhawatirkan 
bukan menyadarkan seseorang tersebut namun malah ikut terjerumus.

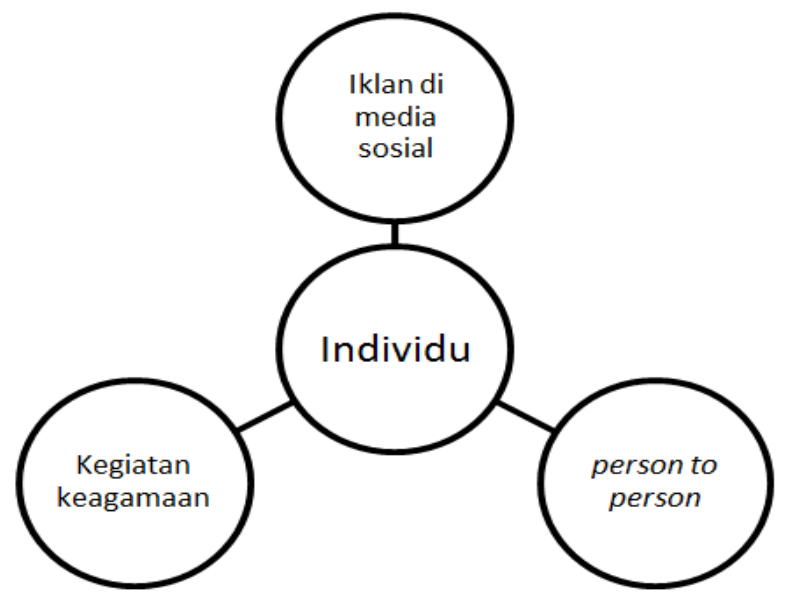

Gambar 4 Tindakan Represif

Permasalahan lesbian bukanlah sebuah permasalahan yang semata-mata harus ditangani pemerintah saja, namun juga harus didukung dengan peran aktif masyarakat. Lesbian juga bukan permasalahan musiman yang bisa terjadi lalu berhenti saat musimnya telah usai. Masalah ini menjadi serius karena terjadi secara kontinyu, begitupun penanganannya harus dijalankan secara terus-menerus. Jangan karena isu yang sudah tidak hangat, dapat mengendurkan penanganannya. Viralkan penolakan lesbian di manapun, beritakan permasalahan LGBT di media massa agar menggentarkan dan menyentuh benak kesadaran mereka. Sadarkan masyarakat yang di lingkungannya diketahui ada pasangan LGBT agar membantu menyadarkan dimulai dari nasihat.

Pada dasarnya dalam menangani lesbian pemerintah hanya berperan untuk membantu menyadarkan dan memfasilitasi. Kesadaran individu berperan penting untuk mengembalikan orientasi seksual seseorang. Perilaku penyimpangan seksual sangat tidak relevan dengan bangsa Indonesia, karena Indonesia adalah negara ketuhanan yang berlandaskan pancasila. Maka dari itu, bekal ilmu agama sangat diperlukan untuk hal ini karena tidak ada satupun agama yang mengamini perilaku menyimpang. Setiap individu yang sudah terbesit dalam hatinya untuk berubah, harus lebih mendekatkan diri dengan Tuhan dan perlahan menguramgi interaksi dengan orang-orang atau kelompok penyimpangan sosial.

\section{KESIMPULAN DAN IMPLIKASI}

Saat pertama kali menjadi seorang lesbian, seseorang tersebut akan berusaha mencari teman lesbian untuk menemukan pengakuan dari kelompok. Menurut data yang diperoleh, dari sembilan aspek dalam faktor yang mempengaruhi terjadinya Atraksi Interpersonal, lesbian di Kota Sukabumi hanya mengalami 8 aspek dan ada 7 aspek yang mempengaruhi dengan kuat yaitu : kesamaan karakterisik personal, tekanan emosional, daya tarik fisik, ganjaran, familiarity, kedekatan, dan kemampuan. Harga diri yang rendah dan Isolasi sosial tidak berpengaruh kuat dalam atraksi interpersonal lesbian.

Program yang disiapkan pemerintah untuk menangani lesbian atau LGBT dinilai belum mampu menjadi solusi yang tepat untuk menangani lesbian. Berdasarkan data yang didapatkan dari kelima informan maka peneliti membuat rekayasa model penanganan lesbian, yaitu sebagai berikut.

\section{Tindakan Preventif}

Dalam hal ini, peneliti membagi model penanganan berdasarkan tingkat pendidikan. Karena, disesuaikan dengan daya tangkap individu tersebut. Penyuluhan kepada masyarakat; agar orang dewasa khusunya orang tua memberikan perhatian lebih kepada anak usia sekolah dasar agar terhindar dari penyipangan seksual dan mengenali rekan bermain anak. Karena empat dari lima informan menyebutkan bahwa sudah mulai tertarik pada sesama jenis sejak sekolah dasar. Menginjak masa sekolah menengah, merupakan masa peralihan dari anak-anak menjadi dewasa sehingga perhatian orang tua dan guru sangat diperlukan. Penyuluhan di Sekolah Menengah Atas/sederajat dan kajian-kajian ke agamaan; mengenai 
bahaya dari perilaku lesbian pada masa sekolah menengah atas daya pikir sudah cukup matang sehingga dapat dilakukan kajian serta seminar langsung pada individu tersebut.

2. Tindakan Represif

Menurut data yang didapatkan, informan mulai berani menjalin hubungan dengan sesama jenis dimulai dari Sekolah Menengah Pertama. Pada masa ini, orang tua sudah membekali anak-anak dengan gadget, bahkan dari mulai sekolah dasarpun ada yang sudah dibekali. Dengan mudahnya anak usia SMP bermain sosial media, terlebih orang dewasa, maka dari itu peneliti menilai iklan di media sosial efektif untuk menangani lesbian. Misalkan, muncul di feed atau story Instagram atau dapat juga memanfaatkan jasa endorse kepada akun berfollowers tinggi atau yang biasa disebut dengan "Selebgram". Selain program person to person yang dilakukan oleh dinas sosial, juga dapat dilakukan kegiatan keagamaan seperti mengaji atau kultum. Mengingat sulitnya pengiriman lesbian ke panti rehabiliasi, peneli menilai seorang lawan jenis atau laki-laki juga efektif untuk menangani lesbian, jika mempunyai teman yang merupakan penyuka sesama jenis dan berniat menyadarkan, alangkah lebih baiknya dibantu disadarkan oleh lawan jenis. Jika oleh sesama jenis dikhawatirkan bukan menyadarkan malah ikut terjerumus.

\section{DAFTAR PUSTAKA}

Arikunto, S. 2006. Prosedur Penelitian. Yogyakarta : Rineka Cipta.

Famela, Ajeng. 2018. Transendensi Pancasila: Langkah Penguatan dan Rekonstruksi Peran Pemuda Indonesia
Dalam Menyikapi Problema LGBT (Lesbian, Gay, Biseksual, Transgender). Bogor: Universitas Djuanda.

Fatimah, Puti Nurul. 2012. Upaya-upaya Pemulihan Mantan Lesbian. Empathy. Volume (1): 122-130.

Hidayat, Rahmat. 2015. Kajian Bentukbentuk Eksploitasi Seks Komersial Anak Di Lingkungan Wisata Provinsi Sulawesi Utara. Sosiohumaniora. Volume (17): 244-254.

Khairina, Rizka. 2013. Implementasi Teori Atraksi Interpersonal dalam Hubungan Pasangan Lesbian. Depok : Universitas Indonesia.

Kristian Erdianto. 2018. DPR-Pemerintah Belum Sepakat Pasal LGBT dalam RKUHP Ditunda. Kompas.com. Diakses pada tanggal 16 Juni 2018.

Miles, B. B., dan A. M. Huberman. 1992. Analisa Data Kualitatif. Jakarta : UI Press.

Olson, James, T. 2000. Sexuality. New York : Free Press.

Rahman, Abdul Agus. 2013. Psikologi Sosial: Integrasi Pengetahuan Wahyu dan Pengetahuan Empirik. Jakarta : Rajawali Pers.

Rahmat, Jalaludin. 2008. Psikologi Komunikasi. Bandung: PT. Remaja Rosdakarya.

Ruslan, Rosady. 2004. Metode Penelitian: Public Relations dan Komunikasi. Jakarta : PT RajaGrafindo Persada.

Scott, John. 2011. Sosiologi (The Key of Concepts). Jakarta: PT. RajaGrafindo Persada.

Suyanto Bagong, dan Sutinah. 2015. Metode Penelitian Sosial Berbagai Alternatif Pendekatan Edisi Ketiga. Jakarta: Prenadamedia Group.

Undang-undang (UU) Negara Republik Indonesia Nomor 1 Tahun 1974 tentang perkawinan. 